\title{
IMPLEMENTASI DAN ANALISA KINERJA VOIP SERVER PADA JARINGAN WIRELESS LAN MENGGUNAKAN SMARTPHONE
}

\author{
Muhammad Saleh Abrar ${ }^{1}$, Rudy ${ }^{2}$ \\ 1,2 Jurusan Teknik Elektro Universitas Borneo Tarakan, Tarakan, Kaltara, Indonesia \\ email: ${ }^{1}$ muhammadsalehabrardgmail.com, ${ }^{2}$ rudy232@gmail.com
}

\begin{abstract}
This research aims to implement VoIP Server In Wireless LAN network at Faculty of Engineering Universitas Borneo Tarakan by using Elastix as a server and VoIP Call application on Smartphone using CsipSimple and analyze the performance of the server with Wireshark software. The method used in this study is by measuring the quality of service or QoS (Quality of Service). Testing is done indoor and outdoor. With QoS parameters such as delay, throughput, and packet loss can be used as a measure to determine the quality of a network. The biggest delay in indoor testing is 11-15 meters, which is 0.00956464 seconds. Packet loss is generated at $0.00 \%$ range, while the standard packet loss set by ITU-T for VoIP application service is <3\%. The resulting jitter is between $0.04608-0.09485$ seconds while the standard set by ITU-T is $=0-75 \mathrm{~ms} .$. Throughput generated in the testing process ie between $104.551 \mathrm{kbps}-108.905 \mathrm{kbps}$.
\end{abstract}

Keywords-Voice over Internet Protokol, Elastix, Quality of Service, Wireshark

Intisari-Penelitian ini bertujuan untuk mengimplementasikan VoIP Server Pada jaringan Wireless LAN di Fakultas Teknik Universitas Borneo Tarakan dengan menggunkan Elastix sebagai server dan aplikasi VoIP Call pada Smartphone menggunakan CsipSimple serta menganalisa kinerja dari server tersbut dengan perangkat lunak Wireshark. Metode yang digunakan dalam penelitian ini yakni dengan metode pengukuran kualitas layanan suara atau QoS (Quality of Service). Pengujian dilakukan indoor dan outdoor. Dengan parameter QoS sepeti delay, throughput, dan packet loss dapat dijadikan sebagai ukuran untuk mengetahui kualitas dari suatu jaringan. Delay yang dihasilkan paling besar di pengujian indoor dengan jarak 11-15 meter yakni sebesar 0.00956464 seconds. Packet loss yang dihasilkan pada range $0,00 \%$, sedangkan standar packet loss yang ditetapkan oleh ITU-T untuk layanan aplikasi VoIP adalah < 3\%. Jitter yang dihasilkan yakni antara 0,04608 - 0.09485 seconds sedangkan standar yang ditetapkan oleh $I T U-T$ adalah $=$ 0-75 ms.. Throughput yang dihasilkan pada proses pengujian yakni antar 104,551 kbps - 108,905 kbps

Kata Kunci-Voice over Internet Protokol, Elastix, Quality of Service, Wireshark

\section{PENDAhuluan}

Voice over Internet Protocol adalah Teknologi yang menjadikan media internet untuk bias melakukan komunikasi suara jarak jauh secara langsung. Sinyal suara analog, seperti yang kita dengar ketika berkomunikasi di telepon diubah menjadi data digital dan dikirimkan melalui jaringan berupa paket-paket data secara real time. Dalam komunikasi VoIP, pemakai melakukan hubungan telepon melalui terminal yang berupa PC atau telepon biasa. Dengan bertelepon menggunakan VoIP, banyak keuntungan yang dapat diambil diantaranya adalah dari segi biaya jelas lebih murah dari tarif telepon seluler. Selainitu, biaya maintenance dapat di tekan karena voice dan data network terpisah, sehingga IP Phone dapat di tambah, dipindahdan di ubah. Hal ini karena VoIP dapat dipasang disembarang Ethernet dan IP address, tidak seperti telepon konvensional yang harus mempunyai port tersendiri di Sentral atau PBX (Private branch exchange).

\section{METODE}

Untuk penelitian ini akan mengimplementasikan layanan tersebut di wilayah Fakultas Teknik Universitas Borneo Tarakan dengan menggunakan perangkat Smartphone, yang memiliki kemampuan mobilitas yang tinggi dan dengan memanfaatkan Wifi (Wireless Fidelity) yang telah terintegrasi pada perangkat tersebut.baterai. Berbagai studi mengenai Voice Over Internet Protokol (VoIP) yang telah dilakukan seperti mengenai paket delay VoIP dalam single hop di jaringan Ad Hoc IEEE 802.11.

Studi tersebut memperkenalkan prediksi model VoIP pada IEEE 802.11 untuk jaringan ad hoc. Model tersebut digunakan untuk mengetahui dampak atau prediksi delay yang terjadi pada VoIP melalui parameter konfigurasi seperti codec, packetization interval dan data rate. Studi berikutnya mengenai komunikasi VoIP di jaringan wireless ad hoc melalui gateway dilakukan oleh Faloso et.al (Fasolo et al., 2007). Studi tersebut memperkenalkan rumus untuk memperkirakan jumlah sesi suara berkelanjutan dalam satu hop cell. Keakuratan rumus tersebut dapat diimplementasikan melalui perangkat lunak simulasi jaringan NS2.

\section{A. Voice Over Internet Protokol (VoIP)}

Di banyak negara, khususnya, Negara-negara berkembang, orang-orang berusaha untuk solusi komunikasi murah. Hal ini, internet menjadi lebih mudah diakses bagi orang dan korporasi di Negaranegara tersebut. Memiliki akses ke internet, seseorang mungkin mudah menyebarkan jaringan telepon di atas infrastruktur internet. Hal ini dikenal sebagai Voice 
over Internet Protocol (VoIP) juga dikenal sebagai Internet Telephony.

VoIP sendiri ialah teknologi yang memungkinkan komunikasi suara dan fax menggunakan jaringan berbasis IP (Internet Protocol) untuk dijalankan diatas infrastruktur jaringan packet network. Jaringan yang digunakan bisa berupa internet atau intranet. Teknologi ini bekerja dengan jalan merubah suara atau fax menjadi format data digital tertentu yang dapat dikirimkan melalui jaringan IP. VoIP memiliki prinsip Kerja mengubah suara analog yang didapatkan dari speaker pada Komputer menjadi paket data digital, kemudian dari $P C$ diteruskan melalui $\mathrm{Hub}$ / Router/ ADSL Modem dikirimkan melalui jaringan internet dan akan diterima oleh tempat tujuan melalui media yang sama. Atau bisa juga melalui media telepon diteruskan ke phone adapter yang disambungkan ke internet dan bisa diterima oleh telepon tujuan.

\section{B. Transmission Control Protocol (TCP)}

Merupakan protokol yang menjaga reliabilitas hubungan komunikasi end- to-end. Konsep dasar cara kerja TCP adalah mengirim dan menerima segmensegmen informasi dengan panjang data bervariasi pada suatu datagram internet. Dalam hubungan VoIP, TCP digunakan pada saat signaling, TCP digunakan untuk menjamin setup suatu panggilan pada sesi signaling. TCP tidak digunakan dalam pengiriman data suara karena pada komunikasi data VoIP penanganan data yang mengalami keterlambatan lebih penting daripada penanganan paket yang hilang.

\section{User Datagram Protocol (UDP)}

Merupakan salah satu protocol utama diatas IP, yang lebih sederhana dibandingkan dengan TCP. UDP digunakan untuk situasi yang tidak mementingkan mekanisme reliabilitas. UDP digunakan pada VoIP pada pengiriman audiostreaming yang berlangsung terus menerus dan lebih mementingkan kecepatan pengiriman data agar tiba di tujuan tanpa memperhatikan adanya paket yang hilang walaupun mencapai $50 \%$ dari jumlah paket yang dikirimkan. Karena UDP mampu mengirimkan data streaming dengan cepat.

\section{SIP (Session Initiation Protocol)}

Yaitu protokol yang digunakan untuk inisiasi, modifikasi dan terminasi sesi komunikasi VoIP. SIP adalah protokol Open Standard yang dipublikasikan oleh IETF, RFC 2543 dan RFC 3261. Selain digunakan untuk negosiasi sesi komunikasi voice, SIP juga dapat digunakan untuk negosiasi sesi komunikasi data media lain seperti video dan text. Disebutkan sebagai hanya melakukan "negosiasi sesi komunikasi" adalah karena SIP merupakan signalling protocol, bukan media transfer protocol. Artinya SIP tidak menghantar data media (voice, video dan text), melainkan hanya melakukan negosiasi sesi komunikasi saja dan memanfaatkan protokol lain seperti $R T P$ sebagai media transfer protocol.

\section{E. Quality Of Service VoIP}

Pembahasan selanjutnya adalah mengenai metode yang digunakan dalam penelitian ini untuk mengukur kualitas kinerja VoIP. Secara umum, ada beberapa parameter-parameter penting yang mempengaruhi Quality of Service (QoS) layanan suara pada jaringan VoIP. Parameter ini dijadikan gambaran ukuran kinerja dari suatu jaringan VoIP. Parameter QoS tersebut yakni delay, jitter, packet loss dan throughput.

\section{F. Delay}

Delay (latency), adalah waktu tunda yang dibutuhkan data untuk menempuh jarak dari asal ke tujuan. Dalam perancangan jaringan VoIP, waktu tunda merupakan suatu permasalahan yang harus diperhitungkan karena kualitas suara bagus tidaknya tergantung dari waktu tunda. Besarnya waktu tunda maksimum yang direkomendasikan oleh ITU-T G.711 untuk aplikasi suara adalah $160 \mathrm{~ms}$, sedangkan waktu tunda maksimum dengan kualitas suara yang masih dapat diterima pengguna adalah $250 \mathrm{~ms}$. Waktu tunda end-to-end adalah jumlah waktu tunda konversi suara analog ke digital, waktu tunda waktu paketisasi atau bisa disebut juga waktu tunda panjang paket dan waktu tunda jaringan pada saat $\mathrm{t}$ (waktu) tertentu.

Untuk menghitung delay yang terjadi digunakan Persamaan 1 (Setiawan, 2012)(Suryawan, Husni,\& Anggraini, 2012).

Delay $=\frac{T}{P}$

\section{HASIL DAN PEMBAHASAN}

Pada penelitian ini dilakukan pengukuran kualitas suara dengan menggukan metode $Q o S$. Jaringan yang digunakan untuk menghubungkan antara satu Smartphone (device) dengan Smartphone yang lain digunakan jaringan wireless $L A N$ di Fakultas Teknik Unuversitas Borneo Tarakan. Saat terjadi komunikasi antar satu Smartphone dengan Smartphone yang lain, data komunikasi yang terjadi di jaringan diambil menggunakan perangkat lunak wireshark. Kemudian hasil capture data jaringan oleh perangkat lunak wireshark tersebut dianalisis melalui pendekatan parameter delay, throughput dan packetloss. Pendekatan tersebut dilakukan untuk mengetahui kualitas layanan suara yang dihasilkan oleh jaringan VoIP di Fakultas Teknik Universitas Boneo Tarakan.

\section{A. Analisis Sistem}

Analisis system adalah penguraian dari suatu sistem yang utuh kedalam bagian-bagian komponennya, dengan maksud untuk mendapatkan perangkat lunak dan perangkat keras yang dibutuhkan dalam penelitian ini. Analisis tersebut dilakukan agar dalam proses penelitian ini dapat berjalan seperti yang direncanakan. Dalam penelitian ini dibutuhkan perangkat keras dan perangkat lunak sebagai berikut :

1. Analisis Perangkat Keras (Hardware)

Perangkat keras (hardware) adalah sistem utama dari sebuah sistem secara fisik, yang terdiri dari 
komponen-komponen yang saling terkait. Perangkat keras juga dapat dikatakan sebagai device. Device tersebut adalah :

- Satu unit laptop dengan spesifikasi:

a. Network: WiFi 802.11b/g/n, Ethernet Port

a. Support WiFi adaptor / WiFi ad hoc

b. Baterai 5 hours (4-cell battery).

- Dua buah Smartphone dengan spesifikasi minimum:

a. Sistem operasi : Android 4.2 (Jelly Bean)

b. Konektivitas : WiFi $802.11 / \mathrm{b} / \mathrm{g} / \mathrm{n}$

c. Support WiFi direct, WiFi hotspot/ WiFi ad hoc

- Satu buah Acces Point dengan spesifikasi :
a. Model : TD-W8961N
b. Interface : 4 10/100 Mbps RJ45 Ports
c. External Power Supply : 9VDC/0.85A
d. Antenna Type : Omni directional, Fixed
e. Antenna Gain : $2 \times 5 \mathrm{dBi}$
f. Frequency : $2.400-2.4835 \mathrm{GHz}$
g. Transmit Power : $<20 \mathrm{dBm}($ EIRP)

2. Analisis Perangkat Lunak (Software)

Perangkat lunak yang dibutuhkan dalam penelitian ini untuk melakukan uji coba aplikasi VoIP pada jaringanVoIP Server adalah sebagai berikut :

a. CsipSimple, merupakan aplikasi mobile softphone atau aplikasi telepon internet (VoIP) yang menggunakan session intiation protocol (SIP) untuk device android. CsipSimple dapat diperoleh dengan mudah di google play android. Dasar pemilihan aplikasi CsipSimple karena CsipSimple adalah mobile softphone untuk Android yang berlisensi Open Source. Artinya source code nya tersedia bebas dan dikembangkan oleh banyak orang sehingga suatu hari ini nanti sangat mungkin akan menjadi sebuah aplikasi yang handal untuk digunakan sebagai bagian dari Next Generation Network.

b. Wireshark, software untuk mengambil atau mengcapture paket data jaringan internet. Dasar pemilihan aplikasi Wireshark Karena Wireshark mampu menangkap paket - paket data atau informasi yang berjalan dalam jaringan. Semua jenis paket informasi dalam berbagai format protokol pun akan dengan mudah ditangkap dan dianalisa. Karenanya takjarang tool ini juga dapat dipakai untuk sniffing (memperoleh informasi penting seperti password e-mail atau account lain) dengan menangkap paket - paket yang berjalan di dalam jaringan dan menganalisanya. Wireshark juga merupakan salah satu dari sekian banyak tool Network Analyzer yang banyak digunakan oleh Network administrator untuk menganalisa kinerja jaringannya terrmasuk protocol didalamnya. Wireshark banyak disukai karena interfacenya yang menggunakan Graphical User Interface (GUI) atau tampilan grafis.

c. VoIP server, untuk mendapatkan akun SIP seperti username dan password SIP.

\section{B. Pemodelan Sistem}

Gambar 1 memperlihatkan bahwa pemodelan system pada penelitian ini yaitu menggunakan 2 buah Smartphone yang dihubungkan pada server VoIP dengan menggunakan Acces Point Kemudian setelah semua Device terhubung ke Server VoIP dan saling melakukan percakapan dari satu Smartphone ke Smartphone lainnya maka aplikasi Wireshark akan menangkap setiap paket data yang terkirim pada jaringan VoIP Server.

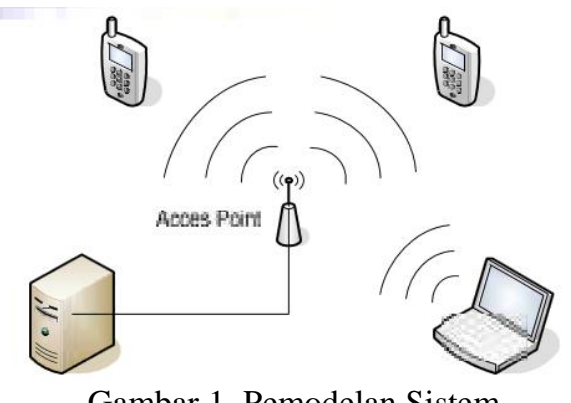

Gambar 1. Pemodelan Sistem

Kemudian kinerja pada jaringan VoIP server dianalisis sesuai dengan parameter delay, throughput, jitter dan packet loss dan perancangan jaringan Voip Server dengan melakukan pengujian pada 1 pasang (2 buah) smartphone Jarak yang berbeda-beda. Pengujian VoIP server dilakukan didalam ruangan (indoor) dan diuar ruangan (outdoor). Percobaan indoor dilakukan dengan semua perangkat baik itu smartphone, server dan acces point berada didalam gedung Fakultas Teknik Universitas Borneo Tarakan. Sedangkan percobaan outdoor dilakukan dengan semua perangkat smartphone, sever dan acces point berada diluar luar gedung yaitu dihalaman parkir Fakultas Teknik Univesitas Borneo Tarakan. Kemudian melakukan panggilan VoIP Call dengan waktu yang sama yaitu selama 1 menit dan jumlah paket suara yang sama pada saya menggunakan file mp3 opick dengan judul alhamduillah. Setelah itu data dicapture menggunakan software wireshark. Kemudian dianalisis sesuai dengan parameter delay, throughput dan packet loss.

C. Jenis dan Sumber Data

Jenis data pada penelitian ini adalah primer dan skunder. Dimana data primer diperoleh dari pengumpulan sendiri secara langsung terhadap objek yang diteliti. Sedangkan untuk data sekunder merupakan data yang diperoleh dari pihak lain seperti buku, datasheet alat yang digunakan, dan acuan lainnya.

D. Total Data Awal

Tabel I

Pengujian VoIP Server Indoor pada jarak 0-5 meter

\begin{tabular}{|c|c|c|}
\hline Jarak & $\begin{array}{c}\text { Jumlah } \\
\text { Paket }\end{array}$ & Total waktu \\
\hline $0-5$ & 6.677 & 62,388 \\
\hline $0-5$ & 6.541 & 62,967 \\
\hline $0-5$ & 6.513 & 61,943 \\
\hline Rata-rata & 6.577 & 62,432 \\
\hline
\end{tabular}


E. Perancangan Sistem

Perancangan sistem merupakan gambaran secara keseluruhan proses kinerja system atau alur jalannya sistem. Pemodelan sistem dalam penelitian ini dapat dilihat pada Gambar 1. memperlihatkan bahwa hal yang pertama kali dilakukan adalah melakukan instalasi software VoIP server yaitu aplikasi Elastix pada komputer. Kemudian melakukan instalasi aplikasi VoIP call di Smartphone android yakni aplikasi CsipSimple. Kemudian Menyeting Acces Point untuk Menyesuaikan IP yang akan digunakan pada VoIP server dan Smartphone. Setelah semua Smartphone terhubung pada VoIP server, kemudian melakukan penentuan skenario pengujian

Tabel II

Pengujian VoIP Server Indoor pada jarak 6-10 m

\begin{tabular}{|c|c|c|}
\hline Jarak & Jumlah paket & Total waktu \\
\hline $6-10$ & 6.931 & 65,228 \\
\hline $6-10$ & 6.840 & 65,333 \\
\hline $6-10$ & 6.768 & 64,777 \\
\hline Rata-rata & 6.846 & 65,112 \\
\hline
\end{tabular}

Tabel III

Pengujian VoIP. Server Indoor pada jarak 11-15 m

\begin{tabular}{|c|c|c|}
\hline Jarak & Jumlah paket & Total waktu \\
\hline $11-15$ & 6.622 & 63,501 \\
\hline $11-15$ & 6.478 & 61,969 \\
\hline $11-15$ & 6.437 & 60,841 \\
\hline Rata-rata & & 64,437 \\
\hline
\end{tabular}

Tabel IV

Pengujian VoIP Server Outdoor pada Jarak 0-5 m

\begin{tabular}{|c|c|c|}
\hline Jarak & Jumlah paket & Total waktu \\
\hline $0-5$ & 6.826 & 62,577 \\
\hline $0-5$ & 6.751 & 63,766 \\
\hline $0-5$ & 6.746 & 60,268 \\
\hline Rata-rata & 6.774 & 62,203 \\
\hline
\end{tabular}

Tabel V

Pengujian VoIP Server Outdoor pada Jarak 6-10 m

\begin{tabular}{|c|c|c|}
\hline Jarak & Jumlah paket & Total waktu \\
\hline $6-10$ & 6.796 & 63,31 \\
\hline $6-10$ & 6.608 & 62,131 \\
\hline $6-10$ & 6.832 & 62,79 \\
\hline Rata-rata & 6.745 & 62,743 \\
\hline
\end{tabular}

Tabel VI

Pengujian VoIP Server Outdoor pada Jarak 10-15 m

\begin{tabular}{|c|c|c|}
\hline Jarak & Jumlah paket & Total waktu \\
\hline $10-15$ & 6.810 & 67,766 \\
\hline $10-15$ & 6.668 & 63,481 \\
\hline $10-15$ & 6.733 & 62,064 \\
\hline Rata-rata & 6.512 & 62,103 \\
\hline
\end{tabular}

Sehingga proses pengujian baik indoor maupun outdoor aplikasi VoIP di jaringan VoIP Sever mendapatkan packet loss dengan menghitung menggunakan Persamaan 3 diperlihatkan pada Tabel VII untuk pengujian indoor dan Tabel VIII untuk pengujian outdoor.

Tabel VII

Hasil Rata-rata Pengukuran Packet Loss (Indoor)

\begin{tabular}{|c|c|c|c|}
\hline $\begin{array}{c}\text { Jarak } \\
(\mathrm{m})\end{array}$ & $\begin{array}{c}\text { Total } \\
\text { Paket }\end{array}$ & $\begin{array}{c}\text { Paket } \\
\text { Terkirim }\end{array}$ & $\begin{array}{c}\text { Packet } \\
\text { Loss }\end{array}$ \\
\hline $0-5$ & 6.577 & 6.577 & $0.00 \%$ \\
\hline $6-10$ & 6.846 & 6.846 & $0.00 \%$ \\
\hline $11-15$ & 6.737 & 6.737 & $0.00 \%$ \\
\hline
\end{tabular}

Tabel VIII

Hasil Rata-rata Pengukuran Packet Loss (Outdoor)

\begin{tabular}{|c|c|c|c|}
\hline $\begin{array}{c}\text { Jarak } \\
(\mathrm{m})\end{array}$ & $\begin{array}{c}\text { Total } \\
\text { Paket }\end{array}$ & $\begin{array}{c}\text { Paket } \\
\text { Terkirim }\end{array}$ & $\begin{array}{c}\text { Packet } \\
\text { Loss }\end{array}$ \\
\hline $0-5$ & 6.774 & 6.774 & $0.00 \%$ \\
\hline $6-10$ & 6.745 & 6.745 & $0.00 \%$ \\
\hline $11-15$ & 6.512 & 6.512 & $0.00 \%$ \\
\hline
\end{tabular}

Hasil pengujian Packet Loss pada Tabel VII dan Tabel VIII menunjukan bahwa Packet Loss yang dihasilkan antara indoor dan outdoor sama yaitu sebesar $0,00 \%$. Standar nilai packet loss jaringan yang ditentukan ITU-T adalah 1 - 3\%, sedangkan nilai ratarata packet loss yang dihasilkan aplikasi VoIP di dalam jaringan VoIP Sever masih diberada di bawah 1\%. Hal tersebut menunjukan bahwa jaringan VoIP Server dapat digunakan untuk aplikasi VoIP.

\section{F. Pengukuran Jitter}

Jitter adalah variasi dari delay. Jitter disebabkan oleh adanya variasi waktu dalam kedatangan paket.Variasi kedatangan paket ini dapat disebabkan oleh panjang antrian data, lamanya waktu pengolahandata dan lamanya waktu yang dibutuhkan untuk menghimpun paket-paket data yang akhir proses transmisi untuk menjadi satu kesatuan frame yang utuh. Software wireshark telah dilengkapi fitur untuk mengetahui jitter komunikasi yang terjadi pada aplikasi VoIP di jaringan VoIP Sever yakni dengan cara membuka menu tab Telephony $\rightarrow$ RTP $\rightarrow$ Show All Streams.

Data jitter yang dihasil oleh software wireshark menggunakan satuan miliseconds (ms) namun dalam penelitian ini data tersebut dikonversikan dengan satuan seconds.

Tabel IX

Hasil Rata-rata Pengukuran Jitter

\begin{tabular}{|c|c|c|}
\hline $\begin{array}{c}\text { Jarak } \\
(\mathrm{m})\end{array}$ & Indoor $(\mathrm{s})$ & Outdoor $(\mathrm{s})$ \\
\hline $0-5$ & 0,05398 & 0,04608 \\
\hline $6-10$ & 0,05461 & 0,05961 \\
\hline $11-15$ & 0,0571 & 0,09485 \\
\hline
\end{tabular}

Pada Tabel IX menunjukkan bahwa pengujian jitter yang paling besar pada percobaan outdoor dengan jarak 11-15 meter yaitu sebesar 0,09485 detik sedangkan nilai pengujian jitter yang paling kecil pada percobaan diluar ruangan (outdoor) dengan 
jarak 0-5 meter yaitu sebesar 0,04608 detik. Pengukuran jitter paling besar dan paling kecil pada outdoor dikarenakan jatuhnya kuat sinyal karena pertambahan jarak pada media transmisi. Setiap media transmisi memiliki redaman yang berbedabeda, tergantung dari bahan yang digunakan. Untuk mengatasi hal ini, perlu digunakan repeater sebagai penguat sinyal. Pada daerah frekuensi tinggi biasanya mengalami redaman lebih tinggi dibandingkan pada daerah frekuensi rendah.

\section{IV.KESIMPULAN}

Berdasarkan hasil penelitian dan pembahasan yang telah dijabarkan dapat diambil beberapa kesimpulan diantaranya: Delay paling besar yang dihasilkan adalah 0.00956464 seconds $(9.56464 \mathrm{~ms})$ pada pengujian di dalam ruangan (indoor) dengan jarak 11-15 meter. Berdasarkan standar ITU-T, kualitas VoIP dapat dikatakan baik jika berada range delay 0-150 ms. Througput yang paling rendah dihasilkan pada proses pengujian didalam ruangan (Indoor) yaitu sebesar $=104,551 \mathrm{kbps}$. Sedangkan throughput yang paling besar dihasilkan pada pengujian diluar ruangan yaitu sebesar $=108,905$ kbps. Packet loss yang dihasilkan pada pengujian baik indoor maupun outdoor yaitu sebesar $0,00 \%$. Berdasarkan standar ITU-T, kualitas VoIP dapat dikatakan baik jika berada range Packet Loss $1-3 \%$. Hal tersebut menunjukan bahwa packet loss yang dihasilkan masih berada pada batas yang ditentukan. Jitter yang dihasilkan berada pada rentang antara $0,04608-0.09485$ seconds. Padahal, Berdasarkan standar ITU-T, kualitas VoIP dapat dikatakan baik jika berada range Jitter $0-75 \mathrm{~ms}$. Namun pada pengujian di outdoor dengan jarak 11-15 meter memiliki jitter yang nilainya melampaui standard yakni sebesar 0.09485 seconds $(94,85 \mathrm{~ms})$.

\section{UCAPAN TERIMA KASIH}

Terima kasih penulis ucapkan kepada segenap pihak yang secara langsung maupun tidak langsung telah berkontribusi baik terhadap proses penyusunan tulisan ini maupun dalam proses publikasinya. Terima kasih kepada para autor yang naskahnya penulis jadikan sebagai referensi.

\section{REFERENSI}

[1] Prasetyo, B. (2006). Analisis Implementasi Voice Over Internet Protocol (VoIP) Pada Jaringan Wireless Lan Berbasis Session Initiation Protocol (SIP).

[2] D. Fahdi, J. P. (2012). Analisa Perancangan Server Voip (Voice Internet Protocol) Dengan Opensource Asterisk Dan Vpn ( Virtual Private Network ) Sebagai Pengaman Jaringan Antar Client.

[3] Indra Warman, Iqbal Marzuki. (2015). Implementasi Voice Over Internet Protocol (Voip) Pada Elastix Server Menggunakan Protocol Inter Asterisk Exchange (Iax). Padang : Institut Teknologi Padang.

[4] Muhammad Saefulloh. (2014). Rancang bangun voip menggunakan Software open Source asterisknow. Surakarta : Universitas Muhammadiyah.
[5] Nurkholis, A., \& Hendrawan, A. (2011). Implementasi Server VoIP untuk Komunikasi di PT. Lintas Data Prima. Yogyakarta: Stmik Amikom.

[6] Ryan Ari Setyawan. (2015) Analisis Unjuk Kerja Aplikasi VoIP Call Android di Jaringan MANET (Mobile Ad Hoc Network). Yogyakarta : Universitas Janabadra.

[7] Setiawan, E. B. (2012). Analisa Quality Of Services (Qos) Voice Over Internet Protocol (VoIP) Dengan Protokol H .323 Dan Session Initial Protocol (SIP). Jurnal Ilmiah Komputer Dan Informatika (KOMPUTA)

[8] Suryawan, K. D., Husni, M., \& Anggraini, E. L. (2012). Analisis Layanan Kinerja Jaringan Voip Pada Protokol Srtp Dan Vpn. Analisis Layanan Kinerja Jaringan Voip Pada Protokol Srtp Dan Vpn.

[9] Yetti Yuniati, Helmy Fitriawan, Domiko Fahdi Jaya Patih. (2014). Analisa Perancangan Server VoIP (Voice Internet Protocol) Dengan Opensource Asterisk Dan Vpn (Virtual Private Network) Sebagai Pengaman Jaringan Antar Client. Lampung : Universitas Lampung. 